\title{
Christian leadership in the workplace - Introduction
}

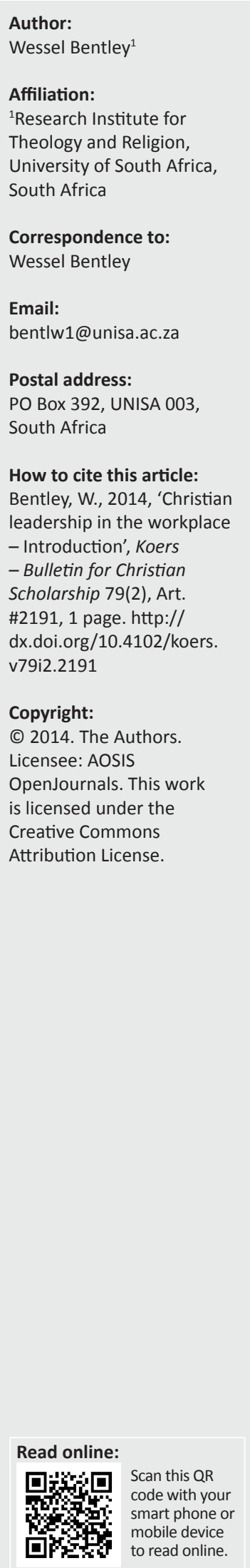

What is Christian leadership and what does it look like in the workplace environment? This special edition of Koers - Bulletin for Christian Scholarship focuses on these questions as they play themselves out in the South African context. Currently, South Africa is celebrating the 20th anniversary of moving into an all-inclusive democracy. This transition has also seen a shift in political orientation, so that South Africa is now recognised as being a secular constitutional democracy. Secular democracies do not favour any specific religion above another and thus Christianity has had to re-evaluate its position and responsibility in the public sphere, especially when it speaks of its leadership contribution. Christian leadership in present-day South Africa must be understood differently from Christian leadership under the apartheid regime - which, coincidentally, itself had a very specific understanding of what it meant to exercise Christian leadership.

The contested space in the discourse on leadership is mostly occupied by purely secular perspectives, so much so that the Christian voice seems to be confined to the exercise of Christian leadership in the context of church life or environments which are exclusively faith based. This runs contrary to the belief that Christians do not leave their faith behind in their places of worship, but that their faith should undeniably influence their contribution in the wider world.

So, if Christians' leadership contribution is coloured by their faith convictions, what, then, does it look like? There is unfortunately not a one-size-fits-all response to this question. Instead, when speaking about Christian leadership, one is led to many other questions, for instance: What is a biblical understanding of leadership in the current South African work context? Can one speak of Christian spirituality in the workplace? How do Christian leaders view the ever-changing workplace environment? Where does a Christian leader's responsibility to ensure morality in the workplace begin and end? What are some of the perpetual political and social paradigms that need to be challenged by Christian leaders, and why?

The articles in this special edition engage with all of these questions, with the ultimate aim of assisting Christians in coming to grips with their unique roles in their respective places of employment and contributing positively in their workplaces. The balance between exercising workplace responsibility whilst being faithful to Christian beliefs is a reality which confronts every Christian, especially as one hears of widespread corruption, discrimination and abuse taking place in this environment. We hope that these articles will stimulate discussion amongst Christians which will lead to constructive workplace environments, not only for Christians, but for all who participate in the South African democratic project.

Readers might also be interested to note that some of the articles that appear in this edition found their beginnings in papers presented at a conference held at the University of South Africa in February 2012 under the conference-theme 'Christian Leadership in the South African Workplace'. It is with great joy and expectation that we commend these articles to you, trusting that they will provide challenge, information and affirmation. 